\title{
Effect of Drying Temperature in the Physiological Quality of Jatropha curcas Seeds
}

\author{
Alessandra Olmo Dardengo ${ }^{1}$, Henrique Duarte Vieira ${ }^{1}$, Bruno Borges Deminicis ${ }^{2}$, Pedro Amorim Berbert ${ }^{3}$, \\ Márcia Terezinha Ramos de Oliveira ${ }^{3} \&$ Erico da Silva Lima ${ }^{4}$ \\ ${ }^{1}$ Laboratório de Fitotecnia, Universidade Estadual do Norte Fluminense Darcy Ribeiro, Campos dos Goytacazes, \\ Rio de Janeiro, Brazil \\ ${ }^{2}$ Centro de Formação em Ciências Agroflorestais, Universidade Federal do Sul da Bahia, Ilhéus, Bahia, Brazil \\ ${ }^{3}$ Laboratório de Engenharia Agrícola, Universidade Estadual do Norte Fluminense Darcy Ribeiro, Campos dos \\ Goytacazes, Rio de Janeiro, Brazil \\ ${ }^{4}$ Programa de Pós-Graduação do Mestrado Profissional em Saúde Ambiental, Centro Universitário das \\ Faculdades Metropolitanas Unidas, São Paulo, Brazil \\ Correspondence: Bruno Borges Deminicis, Centro de Formação em Ciências Agroflorestais, Universidade \\ Federal do Sul da Bahia, Ilhéus, Bahia, CEP 45653-919, Brazil. Tel: 55-73-3214-3288. E-mail: \\ brunodeminicis@gmail.com
}

Received: May 31, 2018

Accepted: July 3, 2018

Online Published: August 15, 2018

doi:10.5539/jas.v10n9p443

URL: https://doi.org/10.5539/jas.v10n9p443

The research is financed by FAPERJ and CAPES, Brazil.

\begin{abstract}
Stimulating the use of renewable energy instead of fossil fuels, especially biofuels, has become one of the alternatives to the issue of global warming. Of these species listed for the production of biodiesel is the Jatropha curcas crop. The aim of this study was to analyze the drying of the seeds of Jatropha, as well as to verify the effect of the different temperatures on the quality of the product, germination percentage and Emergence speed index (ESI). The experimental design was a completely randomized design, with four replications. Experimental drier was used to test the temperatures of $29,35,40,45$ and $50{ }^{\circ} \mathrm{C}$ and the data were compared by regression equation. The vigor and germination of the jatropha seeds were little affected as the drying temperatures were increased to $50^{\circ} \mathrm{C}$.
\end{abstract}

Keywords: germination, physic nut, seed quality

\section{Introduction}

The global warming caused by polluting emissions and the growing greenhouse effect has expand the global concern for the preservation of the environment and has strengthened the agenda for partial or total replacement of fossil fuels by biofuels.

Production of biofuels through the exploitation of energy plant species is considered a sustainable viable alternative, given the diversity of existing oilseeds species and the reduction of the pollutant emissions they provide. Thus, the search for sustainable energetic alternatives requires evaluation of new renewable sources that present less impact to the environment (Da Silva et al., 2017).

Brazil has great potencial for the biofuels production in most of its territory due to its edaphoclimatics aspects, biodiversity, land and labor availability, such as comproved technical competence in the agricultural sciences field (Matos et al., 2014). An alternative to this demand consists in the development of productives, adapted and resistant varieties of promising oilseeds plants species, as the jatropha (Drumond et al., 2016). This way, Japhora curcas L. has been studied by presenting potencial as a raw material for the production of biodiesel (Virgens, Castro, Loureiro, \& Fernandez, 2017).

Jatropha curcas L. is a small tree of the family Euphorbiaceae, popularly known in Brazil as jatropha, purge pine, among other names (CAB International, 2013). The species origin center is undetermined, but it is believed that it may have been disseminated by Portuguese navigators from Central America and Mexico through the Island of 
Cape Verde and the Guinea-Bissau to other countries in Africa and Asia (Brittaine \& Lutaladio, 2010; Virgens, Castro, Loureiro, \& Fernandes, 2017).

For the improvement of the production process of this crop, the technologies of seed production and conservation are found as limitations, among which is the drying process of the seeds. Drying is the most used process to ensure quality and stability in the post-crop phase of plant products, considering that the decrease in the amount of water in the material reduces the biological activity and the chemical and physical changes that occur during storage (Ullmann, Resende, Sales, \& Chaves, 2010).

For the drying of seeds several processes can be used among which are the drying of seeds by convection. Convection drying basically constitutes two simultaneous processes; Evaporation of the superficial water of the seeds to the surrounding air; water movement from the interior to the seed surface, due to the water gradient between these two regions (Garcia, Barros, Peske, \& Menezes, 2004).

The quality of the seeds can be evaluated by some tests, after the drying process, among them, the germination test, in which the physiological quality is evaluated, being considered the main parameter used to evaluate the same. The test allows to know the germination potential of a batch under favorable conditions, and the results being used to determine the sowing rate, for the comparison of the batches value and for the commercialization, since it allows obtaining comparable results between laboratories (Carvalho \& Nakagawa, 2000).

The germination test must follow the recommended standard procedure by the RAS (Rules for Seed Analysis), official publication that regulates seed analysis, to be reproducible, and the germination to occur under optimum conditions for each species (Brasil, 2009).

The germination test applied to evaluate the physiologic quality of seeds from cultivated plants does not have methodology designed specifically for physic nut (Da Silva et al., 2017). Therefore, in the absence of a protocol for germination of jatropha seeds test, Beltrão, Silva, Vasconcelos, Azevedo, and Vieira (2001) have used for analysis the same conditions indicated for castor bean (Ricinus communis L.), belonging to the same family (Euphorbiaceae) and the same genus. In addition to high oil content and being a native species of tropical climate. In this way, investigations on different drying methods become necessary in the production and seed technology of this species. Thus, the objective of this work was to verify the effect of the drying temperature under the physiological quality of the seeds of jatropha.

\section{Material and Methods}

There were used Jatropha curcas L., from the Capixaba Institute for Research and Technical Assistance and Rural Extension (INCAPER), in the city of Linhares, state of Espírito Santo, Brazil. Fruit crop and the processing were performed manually. Part of these seeds was then used to evaluate their physiological potential before performing any convection drying procedure (control treatment).

The initial water content of the seeds was determined before the drying test was started, using the temperature of $105^{\circ} \mathrm{C}$ for $24 \mathrm{~h}$ (whole seeds) (Brasil, 2009).

The drying of the jatropha seeds was performed at $0,29,35,40,45$ and $50{ }^{\circ} \mathrm{C}$, with a mean flow of dry air of 0.7 $\mathrm{ms}^{-1}$ using a prototype dryer of thin layer, manufactured by the Industry and Trade of Machines Polidryer Ltda. The drying chamber is composed of three trays of $0.50 \times 0.62 \mathrm{~m}$, constructed of galvanized steel mesh, arranged in the dryer in order to provide tangential airflow.

The seeds were scattered on the perforated bottom of these trays, forming a thin layer of height corresponding to the thickness of a seed. These three trays were arranged on one of the main trays of the drying chamber. The initial seed mass in each one of the trays was determined before the start of drying. That way, the reduction of the water content of the seeds was monitored by gravimetry, weighing the sample tray range at regular intervals of $5 \mathrm{~min}$ in the first $30 \mathrm{~min}$, from $10 \mathrm{~min}$ to the $120 \mathrm{~min}$, from $15 \mathrm{~min}$ to $180 \mathrm{~min}$ and as of $30 \mathrm{~min}$ from $180 \mathrm{~min}$, using a Sartorius digital balance, model BP $4100 \mathrm{~S}$, with an accuracy degree of $0.01 \mathrm{~g}$. The temperature and relative humidity of the drying air were monitored through a psychrometer installed inside the dryer.

In order to uniform the drying of the trays after being weighed, they returned to the dryer, rotating their positions. This procedure was necessary because preliminary tests showed that the drying rate of the seeds in each tray had a slight difference, probably due to the unevenness of the air flow and temperature observed in different positions in the drying chamber.

The drying air velocity was measured by an Airflow anemometer with rotating blades, model AV6, positioned at the air exit of the dryer. The drying air temperature was measured using a mercury thermometer, with scale division equal to $1{ }^{\circ} \mathrm{C}$, placed just below the drying chamber. The velocity and temperature readings were 
recorded one minute before each weighing. The temperature and humidity of the ambient air were measured using the Hygrometer-485 Series digital apparatus, manufactured by Dwyer Instruments, Inc. This monitoring is intended to calculate the psychrometric properties of the drying air using the GRAPSI computer program, developed by Melo, Lopes, and Corrêa (2004).

Drying was stopped only when the water content of the seeds was close to equilibrium for the conditions under which the tests were performed, this means, using five drying air temperatures $29,35,40,45$ and $50{ }^{\circ} \mathrm{C}$. During the drying process, the trays with the samples were weighed periodically until reaching water contents from $49 \%$ to $12 \%$ b.u.; $49 \%$ to $13 \%$ b.u.; $47 \%$ to $12 \%$ b.u.; $48 \%$ to $7 \%$ b.u.; $47 \%$ to $9 \%$ b.u.

Thereupon the drying, part of the sample was used to determine the final water content and the other part was used to perform the physiological quality tests under laboratory conditions. Because there are no specific rules or norms established for the evaluation of the physiological quality of jatropha seeds, the test was based on information contained in Martins, Machado, and Cavasini (2008).

The experimental used was the completely randomized design, using 50 seeds per replicate, with four replications. Experimental drier was used to test the temperatures of $29,35,40,45$ and $50{ }^{\circ} \mathrm{C}$ and the data were compared by Polynomial regression. The germination test was carried out in trays, where the seeds were sown with sand and conditioned in germinator type "BOD" regulated to maintain the constant temperature of $35^{\circ} \mathrm{C}$ and photoperiod of $8 / 16 \mathrm{~h} \mathrm{light/dark.} \mathrm{The} \mathrm{amount} \mathrm{of} \mathrm{water} \mathrm{added} \mathrm{was} \mathrm{equivalent} \mathrm{to} 2.5$ times the mass of the dry substrate, aiming for adequate moistening and, consequently, uniformity of the test. The methodology described by Maguire (1962) was used to obtain the Emergence speed index (ESI) and Germinate Speed Index (GSI), starting the first count on the fifth day after sowing until the tenth day Martins, Machado, and Cavasini (2008).

The data obtained, except for the water content, were submitted to analysis of variance, and the data in percent were transformed, before the analysis, into $y=\operatorname{arcsen}(x / 100)^{1 / 2}$ and $y=(x+0.5)^{1 / 2}$ for first counting and hard seeds for presenting data with zero value. The data analysis was performed using ESTAT statistical software (FCAV/UNESP), version 2.0/2001. Averages were compared using the Tukey test at a 5\% probability level. Polynomial adjustments up to the third degree were tested and regression equations for the adjusted data were calculated, choosing those with better fit and higher coefficient of determination $\left(\mathrm{R}^{2}\right)$.

\section{Results and Discussion}

There was no significant interaction $(p>0.05)$ Table 1 shows the average values of the variables associated to the drying conditions, the initial and final conditions of the seeds and the drying time for the test.

Table 1. Average conditions of drying air and the seeds of jatropha and drying time for the temperatures of 29,35 , 40,45 and $50^{\circ} \mathrm{C}$

\begin{tabular}{|c|c|c|c|c|c|}
\hline Drying temperatures & $29^{\circ} \mathrm{C}$ & $35^{\circ} \mathrm{C}$ & $40^{\circ} \mathrm{C}$ & $45^{\circ} \mathrm{C}$ & $50^{\circ} \mathrm{C}$ \\
\hline Temperatures $\left({ }^{\circ} \mathrm{C}\right)$ & $28.8 \pm 1.3$ & $30.0 \pm 1.1$ & $28.9 \pm 0.3$ & $30.3 \pm 1.3$ & $30.6 \pm 1.7$ \\
\hline Mixture ratio $\left(\mathrm{kg} \mathrm{kg}^{-1}\right)$ & $0.014 \pm 0.001$ & $0.016 \pm 0.002$ & $0.016 \pm 0.001$ & $0.016 \pm 0.001$ & $0.016 \pm 0.001$ \\
\hline \multicolumn{6}{|l|}{ Drying conditions } \\
\hline Temperature $\left({ }^{\circ} \mathrm{C}\right)$ & $28.8 \pm 1.3$ & $34.9 \pm 0.9$ & $39.8 \pm 1.3$ & $45.0 \pm 0.3$ & $50.0 \pm 1.3$ \\
\hline Dry air flow $\left(\mathrm{kg} \mathrm{s}^{-1} \mathrm{~m}^{-2}\right)$ & 0 & $0.779 \pm 0.020$ & $0.772 \pm 0.023$ & $0.771 \pm 0.037$ & $0.753 \pm 0.027$ \\
\hline \multicolumn{6}{|c|}{ Initial conditions of the product } \\
\hline Temperature $\left({ }^{\circ} \mathrm{C}\right)$ & 26.8 & 34 & 42 & 45 & 50 \\
\hline Water contents (\% b.u.) & $48.9 \pm 2.5$ & $49.6 \pm 0.8$ & $47.3 \pm 0.5$ & $48.2 \pm 1.7$ & $47.7 \pm 2.2$ \\
\hline \multicolumn{6}{|c|}{ Final conditions of the product } \\
\hline Temperature $\left({ }^{\circ} \mathrm{C}\right)$ & 30 & 35 & 39 & 45 & 50 \\
\hline Water contents (\% b.u.) & $12.0 \pm 0.2$ & $13.3 \pm 1.6$ & $12.4 \pm 2.0$ & $7.1 \pm 0.1$ & $8.9 \pm 0.1$ \\
\hline \multicolumn{6}{|l|}{ Drying time } \\
\hline Time $(\mathrm{h})$ & 20.5 & 11.5 & 10.5 & 11.5 & 8.5 \\
\hline
\end{tabular}

It was observed that, for the seeds submitted to drying at temperatures of $29,35,40,45$ and $50{ }^{\circ} \mathrm{C}$, there were necessary respectively $20 \mathrm{~h}$ and 30 minutes, $11 \mathrm{~h}$ and 30 minutes, $10 \mathrm{~h}$ and 30 minutes, $11 \mathrm{~h}$ and 30 minutes, $8 \mathrm{~h}$ and 30 minutes of drying. If it is possible to reduce the water content from about 49 to $12 \%$ bu, 49 to $13 \%$ bu, $47 \%$ to $12 \mathrm{bu}, 48 \%$ to $7 \mathrm{bu}, 47 \%$ to $9 \% \mathrm{bu}$, in other words, the average drying at temperatures of $29,35,40,45$ and $50{ }^{\circ} \mathrm{C}$ was, respectively, $4.08,3.7,4.0,6.8,5.2$ percentage points of water withdrawn per hour of drying. 
Analyzing the graphical representation of the immediate effect of the drying temperature on the vigor of the jatropha seeds, which means, that one performed immediately after drying the seeds (Figure 1), it was observed that there was a negative effect on the vigor of the seeds as it increased the temperature.



Figure 1. Emergence speed index of Jatropha curcas L. seeds in laboratory conditions submitted to drying in different temperatures

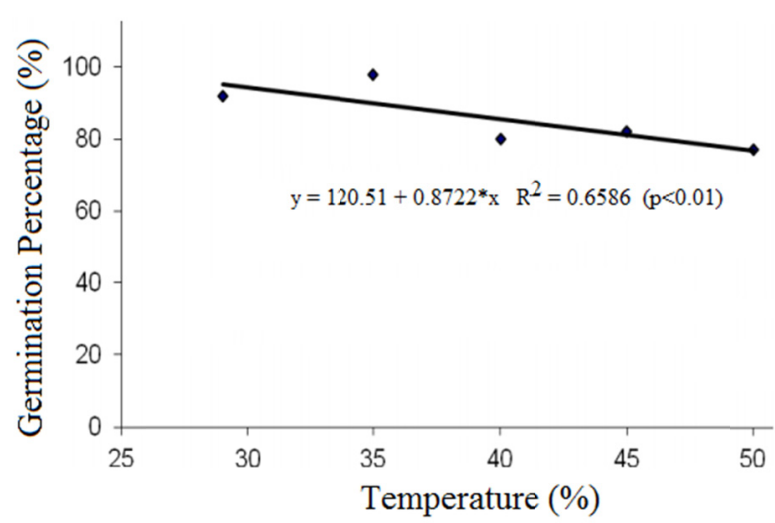

Figure 2. Germination of Jatropha curcas L. seeds in laboratory conditions submitted to drying in different temperatures

These results can be compared to those obtained by Zuchi, Peske, Bevilaqua, and Silva (2009), which dried castor bean seeds of the cultivars Al Guarany 2002 and BRS 188 Paraguaçu produced at Brazilian Agricultural Research Corporation in the unit "Embrapa Clima Temperado" (Pelotas, RS, Brazil) at $40{ }^{\circ} \mathrm{C}$. Results showed that the use of artificial drying at $40{ }^{\circ} \mathrm{C}$ facilitates the production of castor bean seeds of high physiological quality, but higher temperatures are harmful (Zuchi, Peske, Bevilaqua, \& Silva, 2009). In general, the reductions in the physiological quality of seeds are accompanied by the increase in the release of electrolytes and sugars by seeds embedded in water, related to the loss of selective permeability of the cell membranes (Cavariani, Silva, Miranda, Nakagawa, \& Belgiorno, 1998). In the seeds without drying, the average vigor of the seeds was $3.93 \%$, higher than those that were submitted to the drying treatments with the temperatures of $29,35,40,45$ and $50{ }^{\circ} \mathrm{C}$.

Pinto Junior et al. (2012) examining the storage conditions for the maintenance of the physiological quality of jatropha seeds, observed that in the comparison between the effect of the environments and packages, the Emergence speed index (ESI) values of the seeds stored in waterproof packaging (glass) maintained stable values at 90 days of storage, regardless of the storage environment, and the same occurred for the permeable packaging (paper). Also, at 90 days of storage they observed that there was a significant reduction of Emergence speed index (ESI) values when compared to the initial evaluation. 
Resende, Ullmann, Siqueira, Chaves, and Ferreira (2011) studying mathematical models of the drying of jatropha seeds, found that the increase of the drying temperature promotes greater water diffusivity in the seeds, and the activation energy for the net diffusion of the jatropha was $15.81 \mathrm{~kJ} \mathrm{~mol}^{-1}$, indicating that temperatures above $45{ }^{\circ} \mathrm{C}$ during drying reduce germination percentage, but increase seed Emergence speed index (ESI).

In the present study, the results were similar to those verified by Silva, Hisatugo, and Souza, (2016), up to $45^{\circ} \mathrm{C}$, that studying the effect of light on the germination of jatropha seeds of different provenances, verified that there was no difference in the percentage of germination between the seeds of the lots studied and that the average percentage of germination found for the seeds of jatropha (77\%) is considered high. Vanzolini, Meorin, Da Silva, and Nakagawa (2010) and Martins, Machado, and Cavasini (2008) found similar results, where jatropha seeds germinated between 70 and $87 \%$.

It is possible to note that as the drying temperature increases, seed germination decreases. These results agree with Fujii (2007), who also verified that the germination of canola seeds was reduced with increasing drying temperature. In the experiment carried out by Miranda, Silva, and Cavariani (1999) with Soybean (Glycine max) seeds, the results differ where the physiological quality of the seeds was less affected with the higher drying temperature of $50^{\circ} \mathrm{C}$.

According to Brooker, Bakker-Arkema, and Hall (1992), seeds submitted to drying at elevated temperatures undergo by enzymatic degradation processes of germ proteins and the hydrolysis of starch present in the embryo, causing their viability to decrease. However, it is still necessary to understand that the maximum seed exposure temperature will depend on its water content and the time of exposure of the seeds to this condition.

According to Pereira, Martins Filho, and Laviola (2012), temperatures above $45{ }^{\circ} \mathrm{C}$ are also limiting for the germination of Jatropha seeds, preventing their classification by level of vigor due to the severe deterioration of the seeds. However, Oliveira, Dias, Dias, Soares, and Silva (2014) evaluating the efficiency of the accelerated aging test, with variations, for the vigor check of jatropha seeds, verified that the accelerated aging test at 42 or $45^{\circ} \mathrm{C}$ for 48 hours is efficient to classify lots of jatropha seeds at vigor levels.

In the experiment carried out by Ullmann et al. (2010) with drying of seeds of Jatropha at temperatures of 30, 40, 50,60 and $70{ }^{\circ} \mathrm{C}$, the drying at $70{ }^{\circ} \mathrm{C}$ impaired germination due to the possible deterioration of cell membranes of the seeds. From the results, it is possible to verify that drying temperature above $60{ }^{\circ} \mathrm{C}$ removes the water from the interior of the jatropha seeds with greater speed and could cause microcracks in the seed teguments. In the seeds without drying, the germination average of the seeds was $99 \%$, higher than those that were submitted to the drying treatments with temperatures of $29,35,40,45$ and $50{ }^{\circ} \mathrm{C}$.

According to Marcos Filho (2009), the post-harvest drying of the seeds is carried out with the objective of reducing the water content of the seeds to safe levels, being this process of extreme importance, because when it is well conducted, it tends to decelerate the destructive metabolism without promoting seed disturbances. According to Carvalho and Nakagawa (2000), changes in temperature and relative air humidity cause constant adjustments in the water content of the seeds stored in permeable packaging. Seeds of oilseeds should be stored in an environment with lower relative humidity and temperature due to low chemical stability of lipids (Fanan, Medina, Camargo, \& Ramos, 2009).

Borba Filho and Perez (2009), with seeds of Tabebuia roseoalba and Tabebuia impetiginosa, verified that the storage under temperature and reduced humidity maintained the physiological quality of the seeds. In this way, evidencing the importance of the type of packaging to maintain the physiological conditions of the seeds.

Pinto Junior et al. (2012) observed that the seeds stored in glass packaging and refrigerator environment maintained their physiological quality and could be stored for 180 days. For the germination test, no significant effect was observed for the different environments and storage times (90 days, $87 \%$ and 180 days, 89\%) and packaging (90 days, 87\% and 180 days, 90\%). Souza, Bruno, and Andrade, (2005) verified that seeds of Tabebuia serratifolia stored in laboratory environment $\left(27 \pm 3{ }^{\circ} \mathrm{C}\right.$ and $62 \pm 2 \%$ UR) showed total loss of vigor at 120 days of storage.

Pascuali, Da Silva, Porto, Silva Filho, and Meneghello (2012), examining the substrate effect, temperature and light under germination and germination speed index (GSI) of jatropha seeds, observed that the highest percentages of germination were obtained at temperatures of 25,30 and $35{ }^{\circ} \mathrm{C}$, with light and $30{ }^{\circ} \mathrm{C}$ in the absence of light for the substrate sand and that sowing between sand without light at $30^{\circ} \mathrm{C}$ was the one that best promoted the development of the seedlings, with higher Germinate Speed Index (GSI). The combination of the substrate between sand, temperature of $30{ }^{\circ} \mathrm{C}$ and absence of light is the best condition for evaluating the germination and Germinate Speed Index (GSI) of jatropha seeds. 
Ducca, Souza, and Prete (2015) evaluating harvesting times on days after flowering, to maximize oil yield and the physiological quality of jatropha seeds found that, from 75 after flowering, seeds obtained from fruits with yellow staining with brown spots and black seeds show higher values for emergence speed index and percentage of germination. Da Silva et al. (2017) evaluating the adequate stage of maturation for fruit harvest as well as the ideal temperature for germination of jatropha seeds, observed that the maximum germination occurs at a temperature of $35^{\circ} \mathrm{C}$, with yellow fruit seeds with more than $50 \%$ of dark brown with shiny black seeds. Dranski et al. (2010), the seeds originating from the first harvest season did not present germination; therefore, the rate of emergency velocity was also zero at these times.

\section{Conclusions}

The vigor and germination of the jatropha seeds were little affected as the drying temperatures were increased until $50^{\circ} \mathrm{C}$, because the seeds dried at temperatures between 29 and $50{ }^{\circ} \mathrm{C}$, dried between 8 and $20 \mathrm{~h}$, but did not suffer any deleterious effects that significantly affected the germination.

\section{References}

Beltrão, N. E. M., Silva, L. C., Vasconcelos, O. L., Azevedo, D. M. P., \& Vieira, D. J. (2001). Phytology. In D. M. P. Azevedo \& E. F. Lima (Eds.), The agronomy of castor bean in Brazil (pp. 36-61). Campina Grande, Embrapa Algodão.

Borba Filho, A. B., \& Perez, S. C. J. G. A. (2009). Storage of ipê-branco and ipê-roxo seeds in different packages and environments. Brazilian Journal of Seeds, 31(1), 259-269. https://doi.org/10.1590/S0101-31222009 000100029

Brasil. (2009). Rules for Seed Analysis. Brasília: MAPA/ACS.

Brittaine, R., \& Lutaladio, N. (2010). Jatropha: A smallholder bioenergy crop: The potential for pro-poor development (Vol. 8, p. 96). Rome: FAO. https://doi.org/10.1017/S0014479710000542

Brooker, D. B., Bakker-Arkema, F. W., \& Hall, C. W. (1992). Drying and storage of grains and oilseeds. New York: van Nostrand Reinhold.

Carvalho, N. M., \& Nakagawa, J. (2000). Seeds: Science, technology and production (4th ed.). Jaboticabal: FUNEP.

Cavariani, C., Silva, W. R., Miranda, L. C., Nakagawa, J., \& Belgiorno, D. C. (1998). Stationary drying of corn seeds with radial distribution of air flow. Brazilian Journal of Seeds, 20(2), 433-440.

Da Silva, L. M., Felicio, R., Silva, F. C. M., Custódio, I. C., Silveira, P. S., \& Matos, F. S. (2017). Temperature and maturation stage: Its efects on the germination of Jatropha seeds. Journal of Seed Science, 39(1), 27-31. https://doi.org/10.1590/2317-1545v39n1166552

Dranski, J. A. L., Pinto Júnior, A. S., Steiner F., Zoz, T., Malavasi, U. C., Malavasi, M. M., \& Guimarães, V. F. (2010). Physiological maturity of seed sand colorimetry of fruits of Jatropha curcas L. Brazilian Journal of Seeds, 32(4), 158-165. https://doi.org/10.1590/S0101-31222010000400018

Drumond, M. A., De Oliveira, A. R., Simões, W. L., Junqueira, N. T. V., Dos Anjos, J. B., \& Laviola, B. G. (2016). Production and distribution of Jatropha curcas biomass in the Brazilian semiarid region. Cerne, 22(1), 35-41. https://doi.org/10.1590/01047760201622012031

Ducca, C. A. D., Souza, N. M., \& Prete, C. E. C. (2015). Physiological quality and total lipids of Jatropha curcas L. seeds as a function of harvesting times. Brazilian Journal of Agricultural and Environmental Engineering, 19(4), 364-368. https://doi.org/10.1590/1807-1929/agriambi.v19n4p364-368

Fanan, S., Medina, P. F., Camargo, M. B. P., \& Ramos, N. P. (2009). Influence of harvest and storage on the physiological quality of castor bean seeds. Brazilian Journal of Seeds, 31(1), 150-159. https://doi.org/ 10.1590/S0101-31222009000100017

Fujii, K. (2007). Simulation of drying of canola seeds (brassica napus) with germination prediction (Doctoral dissertation). Retrieved from http://repositorio.unicamp.br/bitstream/REPOSIP/257059/1/Fujii_Armando Kazuo_D.pdf

Garcia, D. C., Barros, A. C. S. A., Peske, S. T., \& Menezes, N. L. (2004). The drying of seeds. Rural Science Magazine, 34(2), 603-608. https://doi.org/10.1590/S0103-84782004000200045

Maguire, J. D. (1962). Speed of germination aid in selection and evaluation for emergence and vigour. Crop Science, 2(2), 176-177. https://doi.org/10.2135/cropsci1962.0011183X000200020033x 
Marcos Filho, J., \& Vieira, R. D. (2009). Seed vigor tests: Procedures-conductivity tests. In R. Baalbaki, et al. (Eds.), Seed vigor tests handbook (pp. 186-200). Ithaca: AOSA.

Martins, C. C., Machado, C. G., \& Cavasini, R. (2008). Temperature and substrate for the germination test of Jatropha seeds. Science and Agrotechnology, 32(3), 863-868. https://doi.org/10.1590/S1413-70542008 000300024

Matos, F. S., Carvalho, D. D. C., Souza, A. C., Neves, T. G., Ribeiro, R. P., Cruvinel, C. K. L., ... Santos, P. G. F. (2014). Agronomic viability of the jatropha and soybean consortium. Agrarian Magazine, 7(24), $226-232$. https://doi.org/10.30612/agrarian.v7i24.2262

Melo, E. C., Lopes, D. C., \& Corrêa, P. C. (2004). GRAPSI-Computational program for the calculation of the psychrometric properties of air. Engineering in Agriculture, 12(2), 145-154. Retrieved from ftp://ftp.ufv.br/dea/Disciplinas/Evandro/grapsi/Artigo-v12n2p154-162.pdf

Miranda, L. C., Silva, W. R., \& Cavariani, C. (1999). Drying of soybean seeds in silo with radial distribution of air flow. Brazilian Agricultural Research, 34(11), 2109-2121. https://doi.org/10.1590/S0100-204X199900 1100018

Oliveira, G. L., Dias, L. A. S., Dias, D. C. F. S., Soares, M. M., \& Silva, L. J. (2014). Accelerated ageing test to evaluate vigour in Jatropha curcas L. seeds. Revista Ciência Agronômica, 45(1), 120-127. https://doi.org/ 10.1590/S1806-66902014000100015

Pascuali, L. C., Da Silva, F. S., Porto, A. G., Silva Filho, A., \& Meneghello, G. E. (2012). Germination of physic nut seeds in different temperatures, light and substrates. Semina: Ciências Agrárias, 33(4), 1435-1440. https://doi.org/10.5433/1679-0359.2012v33n4p1435

Pereira, M. D., Martins Filho, S., \& Laviola, B. G. (2012). Accelerated aging of jatropha seeds. Tropical Agriculture Research, 42(1), 119-123. https://doi.org/10.1590/S1983-40632012000100017

Pinto Junior, A. S., Guimarães, V. F., Dranski, J. A. L., Steiner, F., Malavasi, M. M., \& Malavasi, U. C. (2012). Storage of Jatropha seeds in different packages and environments. Brazilian Journal of Seeds, 34(4), 636-643. https://doi.org/10.1590/S0101-31222012000400015

Resende, O., Ullmann, R., Siqueira, V. C., Chaves, T. H., \& Ferreira, L. U. (2011). Mathematical modeling and effective diffusivity of Jatropha curcas L. seeds during drying. Agricultural Engineering, 31(6), 1123-1135. https://doi.org/10.1590/S0100-69162011000600010

Silva, F. J., Hisatugo., E. Y., \& Souza, J. P. (2016). Effect of light on germination and development of Jatropha curcas L. seedlings of different origins. Hoehnea, 43(2), 195-202. https://doi.org/10.1590/2236-89 $06-80 / 2015$

Souza, V. C., Bruno, R. L. A., \& Andrade, L. A. (2005). Stamina of stored seeds of yellow ipê [Tabebuia serratifolia (Vahl.) Nich.]. Revista Árvore, 29(6), 833-841. https://doi.org/10.1590/S0100-676220050 00600001

Ullmann, R., Resende, O., Sales, J. F., \& Chaves, T. H. (2010). Quality of the jatropha seeds submitted to artificial drying. Agronomic Science Magazine, 41(3), 442-447. https://doi.org/10.1590/S1806-6690201 0000300017

Vanzolini, S., Meorin, E. B. K. M., Da Silva, R. A., \& Nakagawa, J. (2010). Sanitary quality and germination of jatropha seeds. Brazilian Journal of Seeds, 32(4), 9-14. https://doi.org/10.1590/S0101-31222010000400001

Virgens, I. O., Castro, R. D. D., Loureiro, M. B., \& Fernandez, L. G. (2017). Review: Jatropha curcas L.: Morphophysiological and chemical aspects. Brazilian Journal of Food Technology, 20, 01-11. https://doi.org/10.1590/1981-6723.3016

Zuchi, J., Peske, S. T., Bevilaqua, G. A. P., \& Silva, S. D. A. (2009). Harvest delay, drying methods and castor bean seed quality. Brazilian Journal of Seeds, 31(3), 09-015. https://doi.org/10.1590/S0101-3122200 9000300001

\section{Copyrights}

Copyright for this article is retained by the author (s), with first publication rights granted to the journal.

This is an open-access article distributed under the terms and conditions of the Creative Commons Attribution license (http://creativecommons.org/licenses/by/4.0/). 